\title{
Digital Competences in the Profile of Teaching Education: Context of Remote Education of Peru
}

\author{
Jhon Holguin-Alvarez ${ }^{1}$, Milagritos Rodríguez Rojas ${ }^{1}$
}

${ }^{1}$ Universidad César Vallejo

1770 Av. Larco, Trujillo 13001, Peru

DOI: $10.22178 /$ pos. $74-7$

LCC Subject Category: L7-991

Received 21.08.2021

Accepted 25.09.2021

Published online 30.09.2021

Corresponding Author:

Jhon Holguin-Alvarez

jhonholguinalvarez@gmail.com

(c) 2021 The Authors. This

article is licensed under a

Creative Commons Attribution

4.0 License @ (1)

\begin{abstract}
Education developed in the virtual context becomes remote today both because of the distance in which school groups are served far from the city, as well as the distance that teachers and students have to reach technological resources to educate and educate themselves, and the resources that affect a higher quality digital education.

In this sense, it is understood that digital skills are essential to generate relevant, comprehensive, inclusive and cooperative virtual educational methodologies, especially during the pandemic, which requires mastery of teaching techniques and mastery of these digital skills. The objective was to determine the causality of digital competencies on the teacher teaching profile. The methodology developed was quantitative, causal, correlational and transactional. The sample consisted of 200 active teachers in Basic Education from a Latin American city. These developed their teaching during the onset of the pandemic (2020) until the middle of the year 2021. The variables were evaluated with Likert-type scales. The reports conclude that the scores in digital competencies present moderate intensity of causality and correlation on the teaching profile of those evaluated. Similar effects were found from digital skills on the cognitive and affective characteristics of the profile, although there are common causal effects on motivation. It is suggested to include other variables in a multi-causal analysis, considering vulnerable contexts in evaluating teachers and their execution during the pandemic.
\end{abstract}

Keywords: basic education; digital competences; distance education; digital teaching; teaching profile; teaching technologies; teaching performance; remote education; virtual skills.

\section{INTRODUCTION}

Quality teaching performance or performance has been stereotyped with teacher training models based on learning by competencies from theoretical perspectives based on complex thinking, knowledge management and human talent, considering its transversal implication in intelligent organizations. This educational model has been reflected in contemporary teachers, implemented through a professional profile under the competence development model. However, from a more prospective model, this educational conception has already changed over time in various European, Asian and even North American contexts, shifting this perspective of the university curriculum towards the conception of global competencies $[2,27]$ and advanced digital skills, proposals from DigComp and DigCompEdu of the European Community $[8,9,23]$. Here is a question to ask: Are low training models based on the competency model reflected in the development of teachers when carrying out educational activities? How much do educational profiles contribute to today's education as a contextual problem? For example, the model based on digital competencies increases the educational profiles of teachers in contexts in which the pandemic has hit economically and socially?

So far, global economic investment still does not allow for the reduction of inequalities. More than USD 160,000 million in the world [28] has been invested in Latin American countries still relegated with the support against the pandemic by SARS-COv-n2 [Covid-19]. Less than $40 \%$ of the global policies for the attention of special needs in education have been met $[10,20]$. Additionally, there are weaknesses in developing global competencies for using modern tools in up to $30 \%$ of the Latin American population, even though 50\% 
of teachers carry out synchronous teaching activities [19].

According to what has already been stated, more than $20 \%$ of the teaching staff population has problems using digital technologies because: how could teachers' digital competence be linked to them with their teaching profiles if they are devoid of the elements necessary for effective education? Are they likely to be related, assuming that they may have low levels of educational effectiveness in a poor context in Latin America such as Peru?... To all this is added that the teaching profile of local teachers is at a low level concerning their performance in teaching [4]: (a) $45 \%$ of teachers do not know the characteristics of the subject they teach, (b) less than $44 \%$ can evaluate themselves on what they do in the classroom [does not reflect], (c) around 70\% of teachers do not know how to adapt the spaces and climate of coexistence during their pedagogical development with their students.

Digital competencies are the capacities and skills that allow the subject to use and understand virtual information and digital tools that allow learning. Both components [capabilities and skills] are currently conceived as a possibility of use $[3,8,9$, $10,17,26]$, so it is argued that capabilities are the skills that allow cognitively and procedurally to use information because this dichotomy has already focused on the arguments of international proposals such as DigCompEdu [16, 23, 26], which propose the development of the competency profile in teachers.

On the other hand, teachers' potentialities of effectiveness over technological tools [hardware-software] determining their professional quality since a digital technological profile is generated corresponding to the subject's capabilities. At present, connectionist approaches are oriented towards the use of technology and the efficiency of its usefulness in the field of action. However, digital constructivist proposals propose using, knowing, and promoting information among subjects who carry out teacher-student and student-student learning. In this sense, skills can be considered the capacity of use and the level with which the activity is achieved, and digital capacities are those skills developed that depend on theoretical and procedural knowledge about the use of information and the technological tools themselves.
Although some researchers in Europe have relied on the DigComp approach to conceptualize digital competencies as skills for the use of technologies, however, the discussion extends to the current proposals of other contemporary authors $[18,22$, 29 ], who involve as part of the competencies the components: (a) knowledge, (b) emotionality, (c) use, and (d) promotion; in teacher professional development. Therefore, the conception of these competencies changes over time. Nevertheless, they are already considered inseparable constructs because teachers act in all required fields of human communication. They add their mediation to achieve learning, and that moment generates necessarily undeniable interrelationships. In the approach of [25] and [24], the needs to develop digital skills allow the recipients (students) to increase: (a) practical development, (b) collaborative learning, (c) technological practices, (d) aspects of thoughtful. Therefore, this concept [with which various contemporary authors agree] outlines the pedagogical practices from the educational training in the university. Therefore, the curriculum does not escape its proposal and considers that digital skills should be included in its programming to develop potentially sustainable societies.

In [26], these competencies have been considered constructs that configure the development of skills and capacities that develop the teaching profile to establish the didactic use of information in the classroom and promote and develop digital competencies in students. For this reason, consider the dimensions: (a) information and information literacy, (b) communication and collaboration, (c) creation of digital content, (d) security, (e) problem-solving. Through the development of capacities, students can achieve practical learning, self-regulated and emotional, since they seek to interact with safe information, achieve active interaction with people, use the information for cognitive development, and search for communication with the world. In this sense, they base their concepts on the theories of connectivism $[7,16]$. However, criticism persists about what connectivism could not establish through informal learning through connections and communicative networks. These attitudinal and emotional components are not involved in developing these skills. Intrinsically advanced digital competencies have been found in teachers who are exposed to demanding situations. In these situations, the economic and social context predetermines their type of teaching [7, 9]. Other studies have 
reported using technological tools implying the use of skills that are not well developed in professional training. This use increases the more practical there is with more current tools $[3,17]$. Finally, the knowledge generated with digital skills can be developed to adapt to the situational context or to the community to which the subject is integrated $[15,21,30]$.

Regarding the teaching profile, in [23], the cultural influence of the teacher was found concerning the global competencies that they demonstrated in teaching, considering technological competencies as part of them since they considered more outstanding authentic commitment and connection with social tradition and culture at the time when the individual considers improving their skills as an element of quality. In this sense, this could be aligned with the study of [13], who considered the teaching perspective based on instruction, organization and emotional interaction. Currently, teaching conditions improve due to the demands of the environment, the capacity of the teacher to organize their didactics, their strategies adapted to the needs of the students. Furthermore, it is necessary to adopt emotional and resilient competencies nowadays since more than $60 \%$ of organizations worldwide cannot make this content more flexible $[1,20]$, avoiding its unity with teaching.

As has already been observed in other studies [2, $13,14]$, teaching ability and its profile have been understood as the ability for instruction. However, the adaptive power of the teacher to various situations irrelevant to the classroom has been ignored [13]. Therefore, the instructive and self-efficacy dimensions $[2,5,6,12]$ were considered and those of a motivational-affective type $[11,12]$. Regarding the research, it was considered essential to perform the teacher from developing skills that allow him to lead in student groups with multiple needs and learning rhythms. Complementing this idea, the working hypothesis is based on the work of [27], who report more significant commitment of the teacher as soon as they perfect their educational teaching practice, involving digital skills as a component of the said profile, this would be reflected as effects positive in the characteristics of cognitive and motivational-affective teaching of the teaching profile, according to raised by [11].

The research hypothesis was dedicated to verifying the causal influence of scores in digital skills on the teaching profile of teachers who practice their profession through virtual teaching in the pandemic context of the year 2021. For this reason, these effects were also verified in the cognitive and affective-motivational characteristics of the profile.

\section{METHODOLOGY}

The method was deductive, transactional, with a non-experimental design. The study reviews the interaction of the digital skills variables as a causal element on the teacher teaching profile scores. In this sense, it is considered a causal-correlational research level. The sample included 200 Regular Basic Education teachers who taught classes from the beginning of the pandemic in 2020 to 2021, using an enveloping sampling (snowball). All belonged to a Latin American city ( $\mathrm{X}=45.6$ years; SD =1.21). Gender presented differences (female $=$ $69 \%$; male $=31 \%$ ). The evaluation was carried out through Google Forms, distributed through text messages and emails through the management of managers interested in the investigation. The general evaluation format for these forms included the record of informed consent for inclusion in the study sample.

Research instruments. Scale for the Exercise of Digital Skills in Teachers [DS-T]. It is a Likert-type scale designed with 25 questions that seek self-assessment of digital competencies at deficient, regular and efficient levels. The grade is polytomous $(1,2,3$ scores) whose answers are raised to sentences of the type: "I use Google Drive to organize class materials...". The components that this scale measures are aimed at evaluating the dimensions: (a) Information and information literacy, (b) Communication and collaboration, (c) Creation of digital content, (d) Safety, (e) Problem solving, by that proposed by [26], based on the DigCompEdu approach of the Common European Framework. Finally, the test can be developed collectively or individually for 10 or 20 minutes.

Teacher Teaching Profile Scale [T-profile]. It is a Likert scale made up of 20 items in proposition format: "I apply techniques to generate lasting learning during class...". Each item has three response alternatives: Always, Sometimes, Never, which have a rating of 1-3 points. The researchbased teaching characteristics of [13] are assessed: (a) Cognitive, (b) Affective, (c) Motivational. The resolution of the scale takes 15 to 25 minutes. 
Opinion Analysis and Preliminary Statistics. Regarding validity, the preliminary versions of the instruments were subjected to expert evaluation. At first, three judges participated who reviewed the criteria of relevance, appropriateness and relationship. Then, after making the linguistic adaptation and appropriate corrections, and after these juries' approval, they were finally passed through two other juries, which qualified the instruments as viable for the study. Table 1 reveals the acceptance percentage in each evaluation case. Regarding the reliability criterion, we sought the analysis of the internal consistency index with a piloting plan with 50 test subjects. The scores obtained revealed acceptable reliability indices for the research (Table 1).

Table 1 - Validity, reliability and correlations of the instruments DS-T and T-Profile

\begin{tabular}{|l|c|c|c|c|c|c|c|}
\hline Scale & $\begin{array}{c}\text { Validation } \\
\text { [Range of } \\
\text { agreements] }\end{array}$ & $\alpha$ & $\begin{array}{c}\text { Information and } \\
\text { information } \\
\text { literacy }\end{array}$ & $\begin{array}{c}\text { Communication } \\
\text { and collaboration }\end{array}$ & $\begin{array}{c}\text { Creation of } \\
\text { digital content }\end{array}$ & Security & $\begin{array}{c}\text { Problem } \\
\text { resolution }\end{array}$ \\
\hline DS-T & {$[98.9-99.3]$} & .940 &, 971 &, 898 &, 807 &, 903 &, 981 \\
\hline $\begin{array}{l}\text { T- } \\
\text { Profile }\end{array}$ & {$[99.5-99.7]$} & .891 &, 977 & Affective & Motivational & & \\
\hline
\end{tabular}

Notes: $\mathrm{a}=$ Cronbach's Alpha; $\mathrm{r}$.a. = Judges acceptance range; ${ }^{\star} \mathrm{p}<.001$.

Additionally, a correlation analysis of components and variables allowed finding high-intensity relationship ranges in Pearson's r Statistic (table 1). This ensured the preservation of groups of components concerning the variables as an experimental data method without resorting to subsequent factor analysis. Once the opinion and reliability analysis had been approved, the evaluation process was managed with the directors involved in each school unit (school) corresponding to the region, those institutions with poor contexts were located to measure the effectiveness of the instruments in teachers faced with the context of a pandemic with austere technological resources, but that demonstrate mastery of technology as part of their teaching skills. The evaluation began in March 2021 and culminated in the first days of June.

\section{RESULTS AND DISCUSSION}

According to the research objective, results were found that allow accepting the central hypothesis. From table 2, it can be determined that digital competencies are influential on the teaching profile of the teachers evaluated as part of the sample. The correlations were significant in the total scores and the general characteristics of the evaluated profile (cognitive, affective, motivational). Moreover, all these relationships were positive and significant. That is, the scores increase in one variable as well as in the others.
On the other hand, the intensity of the relationship between the teaching profile and digital skills was moderate. The correlations of digital competencies and profile characteristics were also moderate, with the relationship between affective characteristics and digital competencies being the one with the most incredible intensity. The one with the lowest relational score was that of motivational characteristics and digital competencies.

Table 2 - Correlations between digital skills, teaching profile and its characteristics

\begin{tabular}{|l|c|c|c|c|}
\hline \multicolumn{1}{|c|}{$r$} & $\begin{array}{c}\text { Teaching } \\
\text { profile }\end{array}$ & $\begin{array}{c}\text { Cognit } \\
\text { ive }\end{array}$ & $\begin{array}{c}\text { Affect } \\
\text { ive }\end{array}$ & $\begin{array}{c}\text { Motivati } \\
\text { onal }\end{array}$ \\
\hline $\begin{array}{l}\text { Digital } \\
\text { Competences }\end{array}$ &, $751^{*}$ &, $681^{*}$ &, $765^{*}$ &, $441^{* *}$ \\
\hline
\end{tabular}

Notes: ${ }^{*} p<.001 ;{ }^{* \star} p<.005$

Once the correlations between variables and components had been verified, the calculation of coefficients of causality and explanation of the linear regression model between them was performed. Table 3 shows the causal correlation coefficient of digital skills influencing the teacher teaching profile, being of moderate power $(\mathrm{R}=0.731)$. It is denoted that the causal power of digital competencies on motivational characteristics was low $(\mathrm{R}=$ 0.321 ), although moderate power indices were found in the other causal effects. This may explain that teachers involved in the search for virtual information, as well as being guided by others to 
handle new technologies, has been critical in mastering virtual environments in teaching classes to their students, as has been mentioned in other studies that determined these digital characteristics in teaching $[8,9,17]$. This has also allowed them to develop new strategies; didactics adapted to the students they would serve in remote education. Many students do not present mastery of the technologies, but many also do not have the opportunity to have resources since teachers have developed techniques to provide feedback on teaching through the search for other social media to ensure that their students develop learning.

This evidence shows that digital competencies have made face-to-face strategies more flexible towards others developed in virtual environments [16, 23]. For this reason, students with fewer resources can share tasks, perform exercises with fewer amounts of data use, borrowed resources, and few materials, which is made possible by teachers who today use virtual environments with multiple tasks. They require few monetary resources as well as technology. Although, according to [4], some essential characteristics may have had adverse effects of teaching in a pandemic, they have likely worsened in those whose teachers did not demonstrate efficient management of the competencies that we analyze in this study. Since more than a year after the pandemic, it is considered that the academic performance is low in the students [19] and the use of didactics in the teachers who already executed them in person.

Table 3 - Correlation coefficients and causal determination between digital skills and the teaching profile

\begin{tabular}{|l|c|c|c|c|}
\hline Components & Teaching profile * & Cognitive & Affective & Motivational \\
\hline $\mathrm{R}$ &, 731 &, 655 &, 702 &, 321 \\
\hline Rs &, 689 &, 641 &, 678 &, 227 \\
\hline gl & 199 & 191 & 197 & 181 \\
\hline F & 356,622 & 251,110 & 302,150 & 119,200 \\
\hline Anova (Sig.) &, 000 &, 001 &, 000 &, 003 \\
\hline
\end{tabular}

Notes: *Predictor: Digital Competences; $\mathrm{Rs}=\mathrm{R}^{2}$

Regarding the determination coefficients (table 3), $69 \%$ of the total model of digital competencies' influence on the teaching profile is explained. In the effects on the profile components, explanations have been found in a range of 64 and $68 \%$ of digital competencies on cognitive and affective characteristics.

Given this, it can be asserted that the development of teachers' classes is oriented towards the development of practical tasks in their teaching, the achievement of cooperative activities, selfknowledge and feedback from students according to what is postulated by [13], even more, since remote education in the context in which the research has been developed, the cultural manifestations of the students are taken as has already been analyzed in other proposals [27], reflected in a national and local curriculum, following their strengths to minimize your weaknesses. Likewise, other investigations suggested that the affective sense of teaching adheres to instructive competence $[2,5,11,12]$ since teaching is inseparable from the power of affectivity between the teacher and the student and the students themselves.
Given this, indexes were found that suggest that teachers are using techniques that accompany teaching through conversations, participation forums, and chat as much as possible to communicate. This raises the possibility that pandemic teaching may present resources to accompany learning and living together at home. Students are likely to feel more related to their teachers as they interact in a period of social isolation. However, others fail to achieve these considerations. On the other hand, only $23 \%$ of the total causal model of digital competencies is explained on the motivational aspect of the teacher teaching profile. This shows a specific rejection of some teachers towards the use of attention strategies, application of individual activities, and the exercise of playful dynamics. What is stated is understood regarding the routes that teachers use since face-to-face social interaction is limited. As shown by some research, digital skills and resources are adapted to the situational context of teaching to the demands of virtual education $[15,30]$. However, it is the opposite. As there is the more excellent utility of technologies, a lower score appears in the ability to socialize in person, limiting itself to verbal 
interaction of a socio-digital type, whether through computers, cell phones or tablets. Finally, it was found that each of the correlational causality models is significant in the sample participants, considering the Anova indices, being less than 5 and $1 \%$ as the minimum error considered for the contrast.

Finally, the resulting values and coefficients, the linear regression of explanation of digital competencies and the teacher teaching profile was formulated. In this, a greater causality value was presented from the variable digital competencies $[\mathrm{PED}=1.60+0.731(\mathrm{DC})]$. Regarding the cognitive dimension [Cog. $=1.20+0.702(\mathrm{DC})]$ and the affective dimension [Afec. $=1.45+0.725(\mathrm{DC})]$ these presented higher scores in the corresponding regression models. The effects of digital competence on the motivational dimension were lower in the regression model $[$ Mot. $=1.02+0.603(D C)]$.

- High level $\quad$ Low level

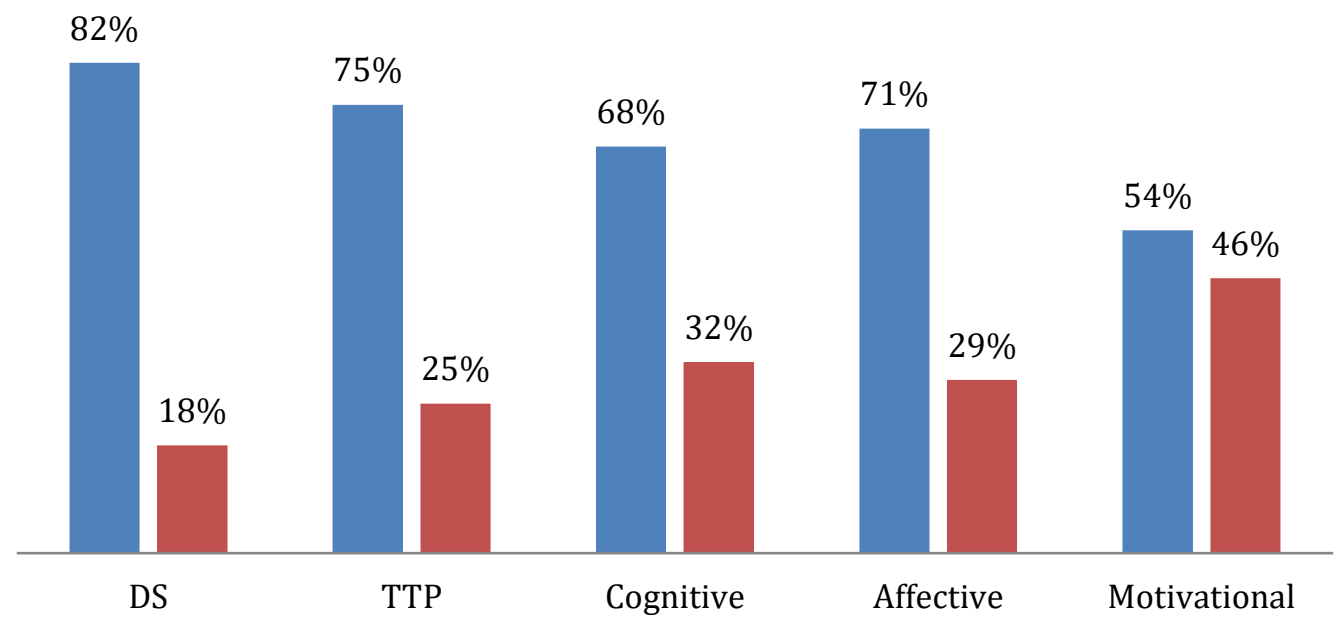

Figure 1 - Percentages in levels in Digital Skills and Teacher Teaching Profile

Notes: DS = Digital Skills, TTP = Teacher Teaching Profile.

The results are shown in Figure 1 support the hypothesis of the influence of digital skills shown by teachers who carry out their pedagogical tasks during the pandemic. Although, more than $80 \%$ of the total sample frame have indeed developed those conditions to benefit the skills of their profile (CD). These skills would have been acquired by more than $70 \%$ of the total population investigated when executing their teaching (TTP) before the appearance of other variables that demanded the development of the capacities of the technological domain. Although it is not the mission of the article, we could only mention those such as the extrinsic and intrinsic needs that appeared as a requirement of the pandemic: (a) lack of economic resources: personal food, family maintenance, (b) lack of technology: Internet wiring, data from the Internet, computers and multimedia devices; (c) social: affectivity, resilience, coping. It is necessary to include other variables such as resilience, self-regulation and virtual dynamics as part of another investigation that finds relationships in teachers who not only work in the pandemic context but also, in those from vulnerable contexts, with feasible socioeconomic problems of be studied, to check the contributions of digital skills on their pedagogy or virtual teaching.

\section{CONCLUSIONS}

Direct and positive influences of the digital skills of a sample of Basic Education teachers were found on their teaching profile, demonstrated through remote or virtual education development during the pandemic context of 2021. Similarly, the effect was moderate and significant on its cognitive and affective characteristics on the teaching profile. The digital competencies also presented causal effects on the affective characteristics of the said profile; although they were significant, they presented low intensity. This shows that the teachers who exercised their professional careers during the development of the classes adopted new techniques to generate cognitive learning (knowledge and procedural), as well as those of an affective communicational type (verbal, 
auditory, visual) since they would be developing new ways to create interactive learning in virtual environments. However, the causal sense and the motivational effects of teaching did not complete the total pedagogical development. Teachers would still have problems developing them in class, and although they are correlated, they do not receive highly positive effects from their digital competencies.

\section{Conflict of interests}

The authors and the institutions involved in the research have no conflicts of interest.

\section{REFERENCES}

1. AON. Creating Future Thinking by Aon. (2020, September 14). Nuevo Informe de Aon: Cómo la Resiliencia está ayudando a las empresas a prosperar en un mundo incierto. Retrieved from https://noa.aon.es/informe-resiliencia-2020/

2. Bae, C. L., Hayes, K. N., \& DeBusk-Lane, M. (2019). Profiles of middle school science teachers: Accounting for cognitive and motivational characteristics. Journal of Research in Science Teaching, 57(6), 911-942. doi: 10.1002/tea.21617

3. Calderón-Garrido, D.; Carrera, X.; \& Gustems-Carnicer, J. (2021). Music Education Teachers' Knowledge and Use of ICT at Spanish Universities. International Journal of Instruction, 14(2), 831-844. doi: 10.29333/iji.2021.14246a

4. Cuenca, R. (2020, September). La evaluación docente en el Perú. https://repositorio.iep.org.pe/bitstream/handle/IEP/1176/Cuenca-Ricardo_Evaluaciondocente-Peru.pdf?sequence=1\&isAllowed=y

5. Errázuriz, L. H., \& Fermandois-Schmutzer, J. (2021). Formación docente para la educación artística en Chile. El desafío cultural pendiente en las escuelas primarias. Arte, Individuo y Sociedad, 33(1), 49-69. doi: 10.5209/aris.67126

6. Gröschner, A., Schindler, A., Holzberger, D., Alles, M., \& Seidel, T. (2018). How systematic video reflection in teacher professional development regarding classroom discourse contributes to teacher and student self-efficacy. International Journal of Educational Research, 90, 223-233. doi: 10.1016/j.ijer.2018.02.003

7. Guizado, F., Menacho, I., \& Salvatierra, A. (2019). Competencia digital y desarrollo profesional de los docentes de dos instituciones de educación básica regular del distrito de Los Olivos, Lima-Perú. Hamut'ay, 6(1), 54-70. doi: 10.21503/hamu.v6i1.1574

8. Hämäläinen, R., Nissinen, K., Mannonen; J., Lämsä, J., Leino, K., \& Taajamo, M. (2021). Understanding teaching professionals' digital competence: What do PIAAC and TALIS reveal about technologyrelated skills, attitudes, and knowledge? Computers in Human Behavior, 117, 106672. doi: 10.1016/j.chb.2020.106672

9. Holguin-Alvarez, J., Apaza-Quispe, J., Ruiz, J. M., \& Picoy, J. A. (2021a). Competencias digitales en directivos y profesores en el contexto de educación remota del año 2020. Revista Venezolana de Gerencia, 26(94), 623-643. doi: 10.52080/rvgluzv26n94.10

10. Holguin-Alvarez, J., Garay-Rodríguez, P., Amasifuén-Sánchez, V., Huaita, D. M., Luza, F. F., CruzMontero, J., \& Ledesma-Pérez, F. (2021). Digital Competences in the Elderly and University Students: Didactic Interaction from the Use of Social Networks. International Journal of Emerging Technologies in Learning, 16(04), 188-200. doi: 10.3991/ijet.v16i04.18519

11. Holzberger, D., Maurer, C., Kunina-Habenicht, O., \& Kunter, M. (2021). Ready to teach? A profile analysis of cognitive and motivational-affective teacher characteristics at the end of pre-service teacher education and the long-term effects on occupational well-being. Teaching and Teacher Education, 100, 103285. doi: 10.1016/j.tate.2021.103285

12. Holzberger, D., Reinhold, S., Lüdtke, O., \& Seidel, T. (2020). A meta-analysis on the relationship between school characteristics and student outcomes in science and maths - evidence from 
large-scale studies. Studies in Science Education, 56(1), 1-43. doi:

10.1080/03057267.2020.1735758

13. Holzberger, D., Praetorius, A.-K., Seidel, T., \& Kunter, M. (2019). Identifying effective teachers: The relation between teaching profiles and students' development in achievement and enjoyment. European Journal of Psychology of Education, 34, 810-823. doi: 10.1007/s10212-018-00410-8

14. Holzberger, D., Philipp, A., \& Kunter, M. (2014). Predicting teachers' instructional behaviors: The interplay between self-efficacy and intrinsic needs. Contemporary Educational Psychology, 39(2), 100-111. doi: 10.1016/j.cedpsych.2014.02.001

15. Howard, S. K., Tondeur, J., Ma, J., \& Yang, J. (2021). What to teach? Strategies for developing digital competency in preservice teacher training. Computers \& Education, 165, 104149. doi: 10.1016/j.compedu.2021.104149

16. Instefjord, E. J., \& Munthe, E. (2017). Educating digitally competent teachers: A study of integration of professional digital competence in teacher education. Teaching and Teacher Education, 67, 3745. doi: 10.1016/j.tate.2017.05.016

17. Lindfors, M., Pettersson, F., \& Olofsson, A. D. (2021). Conditions for professional digital competence: the teacher educators' view. Education Inquiry, 1-20. doi: 10.1080/20004508.2021.1890936

18. Lucas, M., Bem-Haja, P., Siddiq, F., Moreira, A., \& Redecker, C. (2021). The relation between inservice teachers' digital competence and personal and contextual factors: What matters most? Computers \& Education, 160, 104052. doi: 10.1016/j.compedu.2020.104052

19. UNESCO. (2021). Reforzar el aprendizaje y las capacidades digitales en los países más poblados del mundo para estimular la recuperación de la educación. Retrieved from https://es.unesco.org/news/reforzar-aprendizaje-y-capacidades-digitales-paises-maspoblados-del-mundo-estimular

20. UNESCO. (2020). Un nuevo informe de la UNESCO resalta la magnitud de las desigualdades mundiales en la educación y hace un llamado a una mayor inclusión tras la reapertura de las escuelas. Retrieved from https://es.unesco.org/news/GEM-Report-2020

21. Robles Moral, F. J., \& Fernández Díaz, M. (2021). Future Primary School Teachers' Digital Competence in Teaching Science through the Use of Social Media. Sustainability, 13(5), 1-13. doi: $10.3390 /$ su13052816

22. Rubach, C., \& Lazarides, R. (2021). Addressing 21st-century digital skills in schools - Development and validation of an instrument to measure teachers' basic ICT competence beliefs. Computers in Human Behavior, 118, 106636. doi: 10.1016/j.chb.2020.106636

23. Sánchez-Cruzado, C., Santiago, R., \& Sánchez-Compaña, M. T. (2021). Teacher Digital Literacy: The Indisputable Challenge after COVID-19. Sustainability, 13(4), 1858. doi: 10.3390/su13041858

24. Tondeur, J., Scherer, R., Baran, E., Siddiq, F., Valtonen, T., \& Sointu, E. (2019). Teacher educators as gatekeepers: Preparing the next generation of teachers for technology integration in education. British Journal of Educational Technology, 50(3), 1189-1209. doi: 10.1111/bjet.12748

25. Tondeur, J., Van Braak, J., Siddiq, F., \& Scherer, R. (2016). Time for a new approach to prepare future teachers for educational technology use: Its meaning and measurement. Computers \& Education, 94,134-150. doi: 10.1016/j.compedu.2015.11.009

26. Tourón, J., Matín, D., Navarro, E., Pradas, S., \& Íñigo, V. (2017). Validación de constructo de un instrumento para medir la competencia digital docente de los profesores (CDD). Revista Española de Pedagogía, 76(269), 25-54. doi: 10.22550/REP76-1-2018-02

27. Van Werven, I. M., Coelen, R. J., Jansen, E., \& Hofman, Y. (2021). Global teaching competencies in primary education. Compare: A Journal of Comparative and International Education, 1-18. doi: $10.1080 / 03057925.2020 .1869520$ 
28. World Bank. (2020, October 16). Laying the foundations for a resilient recovery. Retrieved from https://www.bancomundial.org/es/news/feature/2020/10/16/laying-the-foundations-for-aresilient-recovery

29. Wild, S., \& Schulze, L. S. (2021). Re-evaluation of the D21-digital-index assessment instrument for measuring higher-level digital competences. Studies in Educational Evaluation, 68, 100981. doi: 10.1016/j.stueduc.2021.100981

30. Zhao, Y., Pinto, A. M., \& Sánchez, M. C. (2021). Digital competence in higher education research: A systematic literature review. Computers \& Education, 168, 104212. doi:

10.1016/j.compedu.2021.104212 